\title{
ELECTRICAL SECTION
}

(Stated meeting held Thursday, November 18, 1909 .

\section{THE ELECTRICAL REDUCTION OF IRON ORE.}

\author{
BY \\ JOSEPH W. RICHARDS, \\ Professor of Metallurgy in Lehigh University; Secretary of the American \\ Electrochenical Society.
}

[The application of the electric current as a source of heat energy in the reduction of iron ores would but a short time ago have scarcely been seriously considered. Its possibility has however been more than demonstrated. In this paper, Dr. Richards describes the work of several investigators in the development and operation of this method of manufacturing pig-iron on a practical commercial scale.]

THIs topic is one which a few years ago could only have been discussed in a speculative manner. and by one with the prophetic gift highly developed. The reduction of iron ore by means of the energy of fuel, in blast-furnaces, is carried on on such a stupendous scale and with such great economy that the blastfurnace has been frequently called our most perfect furnace, and the possibility of electrical energy taking any part in this industry appeared highly visionary. When electric furnaces commenced to be developed on a commercial scale, it was generally admitted that if they entered the iron industry at all their best chance was in the production of highly expensive special quality steels, costing $\$ 500$ to $\$ 1000$ per ton, and that their poorest chance would be to compete in the manufacture of pig-iron costing \$ro to \$ 5 per ton. Yet inside of five short years, those who have watched the development of the electrical iron and steel industry have seen small furnaces turning out fine steels succeeded by larger ones manufacturing successfully common steels, such as steel castings and rail steel, and finally the operation of a larger electric shaft furnace manufacturing pig-iron on a practical commercial scale.

Confining ourselves this evening to the electrical production of pig-iron, most of the credit for the recent advances should 
be given to the far-sighted interest of the Canadian Government in this subject, principally, under the influence of its active Director of the Department of Mines, Dr. Etrgene Haanel, of Ottawa, and to the enterprising Swedes, principally Assar Grönwall, Axel Lindblad and Otto Stalhane, who have founded the company "Aktiebolaget Electrometall" of Ludvika, Sweden. If to these we add the nanles of IT. H. Noble, of the Northern California Power Company, and his able assistant, Prof. D. A. I yon, who have constructed and operated an electric pig-iron furnace in California, the list of active workers in this field is nearly complete.

EXPERIMENTS OF TIL CANADIAN COMMISSION IN EUROPE.

When, in January, 190, the Canadian Government sent a commission, under Dr. ITaanel, "to investigate the different electro-thermic processes for the smelting of iron ores and the making of steel in operation in Europe," the commission found and reported upon a number of different electric-steel fumaces in commercial operation, but found not a single electric pig-iron furnace at work. From the voluminous and most valuable report of this Commission (published by the Canadian Government, August, 1904) we learn that, being interested in seeing what might be accomplished in this direction, several of the European works were persuaded to make some experiments on the production of pig-iron. Some of these tests are described briefly in the following extracts from the report:

At la Praz, France.- "Mr. Héroult was good enough to make some experiments for us in smelting iron ores. The furnace employed was exceedingly simple." . . . "These experiments were made for us by $\mathrm{Mr}$. Héroult for the purpose of demonstrating the simplicity of the process of reducing iron ores by the electric process and it was not intended to demonstrate a figure of cost per ton of pig-iron produced by this process." It appears from the data given that this test was very crucle and poorly arranged. Too little carbon for reduction was used in the charge, the furnace was rum too cold, and the power consumption ran up to $0.5^{2} 5 \mathrm{~h}$. p. year per ton of pigiron obtained.

At Livet, France.-The works of Keller-Leleux et Cie. possessed furnaces constructed for the reduction of ore, and used 
for manufacturing ferro-silicon and ferro-chromiun. These were placed at the disposal of the commission, and two long runs made of 55 and 48 hours each, with all the data carefully controlled and checked. The complete details of these runs can be found in the report of the conmission. Illustrations of the furnace used may be seen in the report. It is of the resistance type, with two shafts, each with its vertical electrode embedded in the charge, and comected by a vell in which metal and slag collect. The current passes from the electrodes to artbon blocks embeded in the base of the fumace. The lining: was a rammed-in mixture of clolomite and tar, similar to that of a basic-lined bessemer converter. The electroles were square, $280 \mathrm{~mm}$. (I I inches) on the side and $1400111 \mathrm{~m}$. (56 inches) long. The 55-hour run was interrupted to put in a watmeter, and the metal set in the furnace, so that the porier consumption for this run $0.52 \mathrm{l}$. p. year per metric ton of pig-iron, was abnormal. In the second run ui 48 hours 110 interruption occurred, the furnace "working quietly, and wilhout the slightest accident: the gases discharging on top in flickering flames, showing that the gas resulting from the reduction of the ore escaped at low pressure. The workmen were ordinary ltalian laborers, without any special training."

This second run was successful in producing, at will, different classes of pig-iron, gray, white, and mottled, and in setting a definite figure for the anom of electric energy required per ton of pigr-iron produced. The furmace was nominally of 300 h. p. capacity, but running with 350 h. p.; it consumed $0.25 \mathrm{~h}$. p. year per metric ton of pig-iron produced. using $4 \mathrm{I}$ per cent. of fuel. This is a satisfactory figure, and is partly attributable to running the furuace hatd, i.e. over its normal capacity.

\section{EXPERIMFNTS OF TILE CANALHAX GOVERNMENT AY SAUTT S. MARTE.}

On the return of the Canadian Commission from Europe, and the publication of its report, the Canadian Government placed at the disposal of Dr. Haanel and his staff \$I 5,000 for investigating the stitability of the electric process for reducing Canadian iron ores. The experiments were carried out early in 1906 , and may be found recorded in detail in the report 
pululished by Dr. Haanel in February, 1907 (Ottawa, Mines Branch, Department of the fnterior). An analytical discussion of these experiments and the results obtained was presented by the speaker to the American Electrochemical Society, at its meeting in New York City, October 18, 1907, and published in the Transactions of that Society, vol. xii, p. 8I. The furnace used is shown in Fig. 1. The following conclusions from the author's analysis may here suffice:

I. Too much carbon was used in every case, not allowing a good utilization of the heat of oxidation of carbon in the furnace. A smaller proportion of carbon, more perfectly consumed to $\mathrm{CO}_{2}$ would have generated moro heat and thus have helped the furnace more.

2. The elcctric current furnisherl about two thirds of the energy required for all purposes, the carbon one third.

3. The consumption of fixed carbon was 24 to $3^{8}$ per cent. of the weight of pig-iron, giving ratios of $\mathrm{CO}$ to $\mathrm{CO}_{2}$ in the gases of 4.5 up to 9 (by volume); whereas a ratio of $I$ is possible, would require far less carbon, and would produce more lieat in the furnace. For the details of this analysis, the reader is referred to the original paper. Some of these figures will be used in the comparative tabulations at the end of this paper. One thing is particularly worth noting: the Sault Ste. Marie furnace was small and was worked hard, a condition favorable for small conduction and radiation loss, and economy of power.

RUNNING OF THE SWEDISH SHAFT FURNACE.

The experinents at Sault Ste. Maric bore fruit first in Sweden, by inciting experimenters there to construct a large electric shaft furnace for the regular commercial production of pig-iron. Messrs. Grönwall, Lindblad and Stahane conducted preliminary experiments at Ludvika, Sweden, in the summer of 1907 , with a small furnace of $300 \mathrm{~h}$. p. capacity; in the summer of 1908 a larger furnace of different type was constructed, and in the autumn of 1908 a still larger furnace, cmbodying the results of all their experience, was completed. This furnace was designed for I 500 kilowatts, and may be truly termed the pioneer electric pig-iron furnace. The best description of this furnace and its working are to be found in a paper by Dr. E. Haanel in the Transactions of the American Electro- 


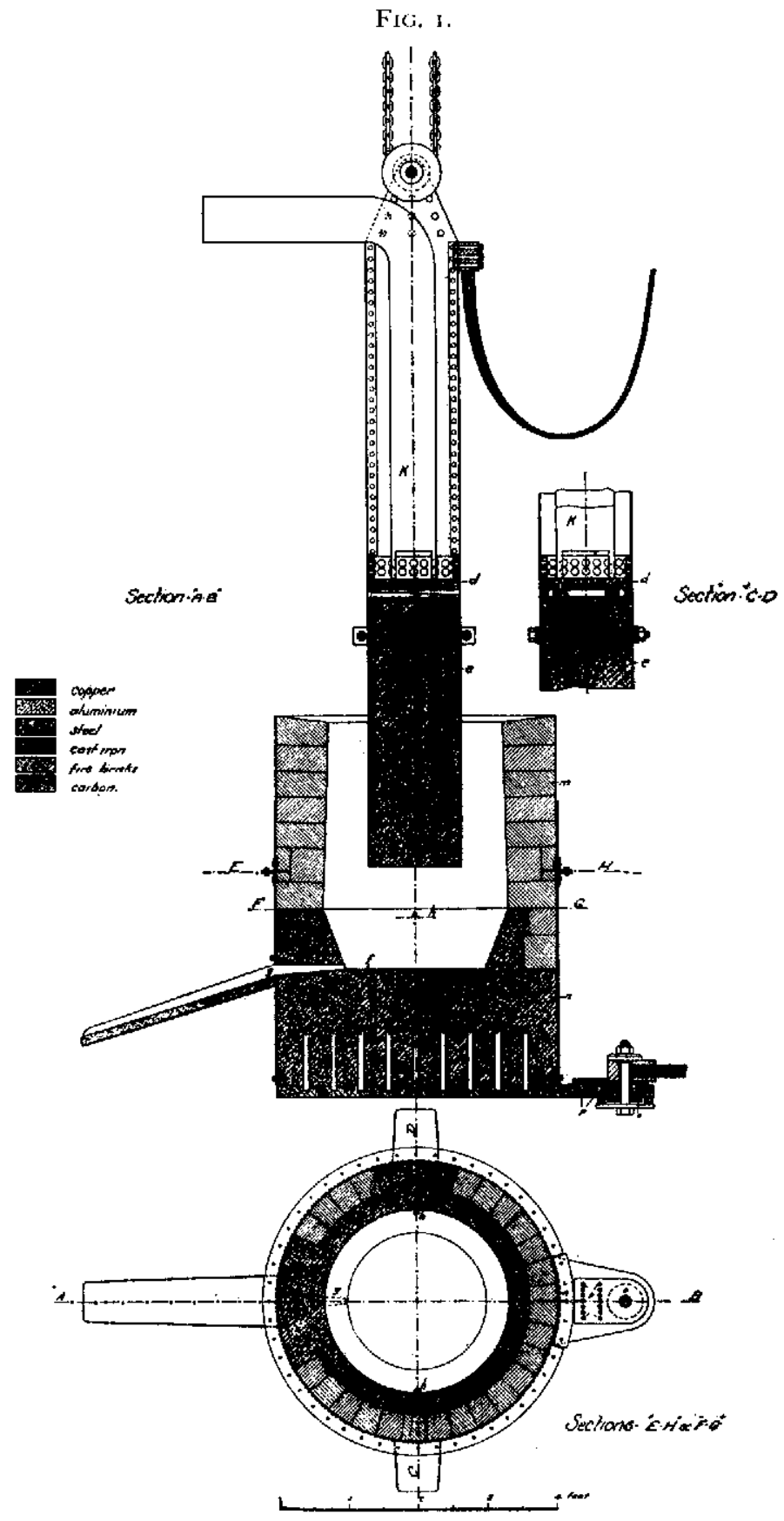

Experimental furnace used at Sault S. Marie. 


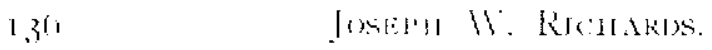

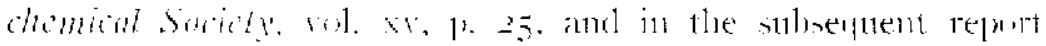

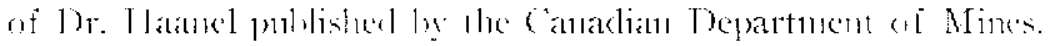

His. 2.

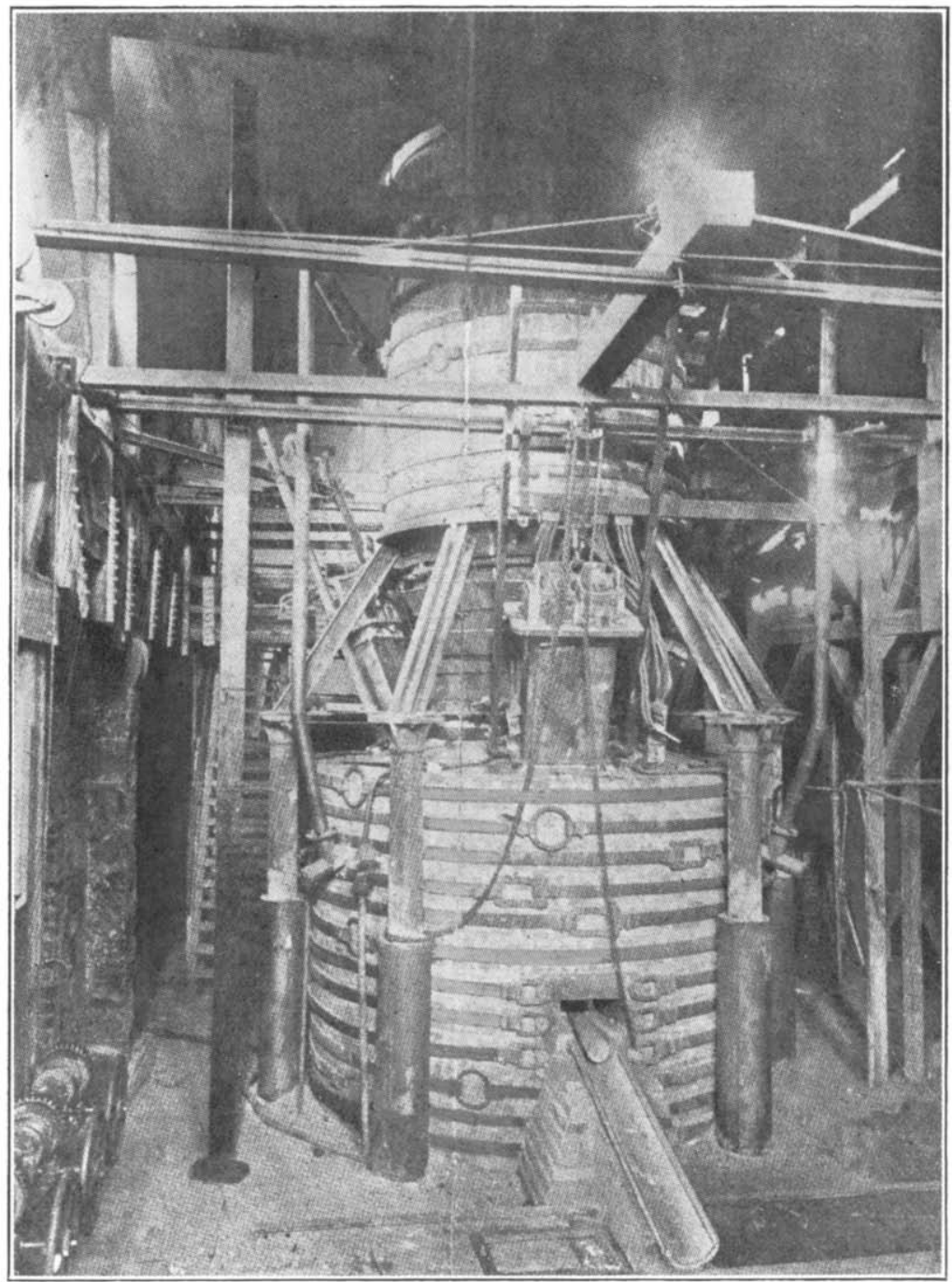

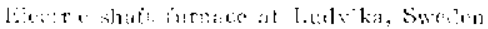

in Ocwber, 1009, critilel "Investigation of an Flectric Shat Furnace at Donulateret. Surolen. The following details and 
illustrations (ligss 2 and 3 ) are taken from Dr. Haanel's publications:

The total hetoht athowe the ground-level is 2.5 feet: the

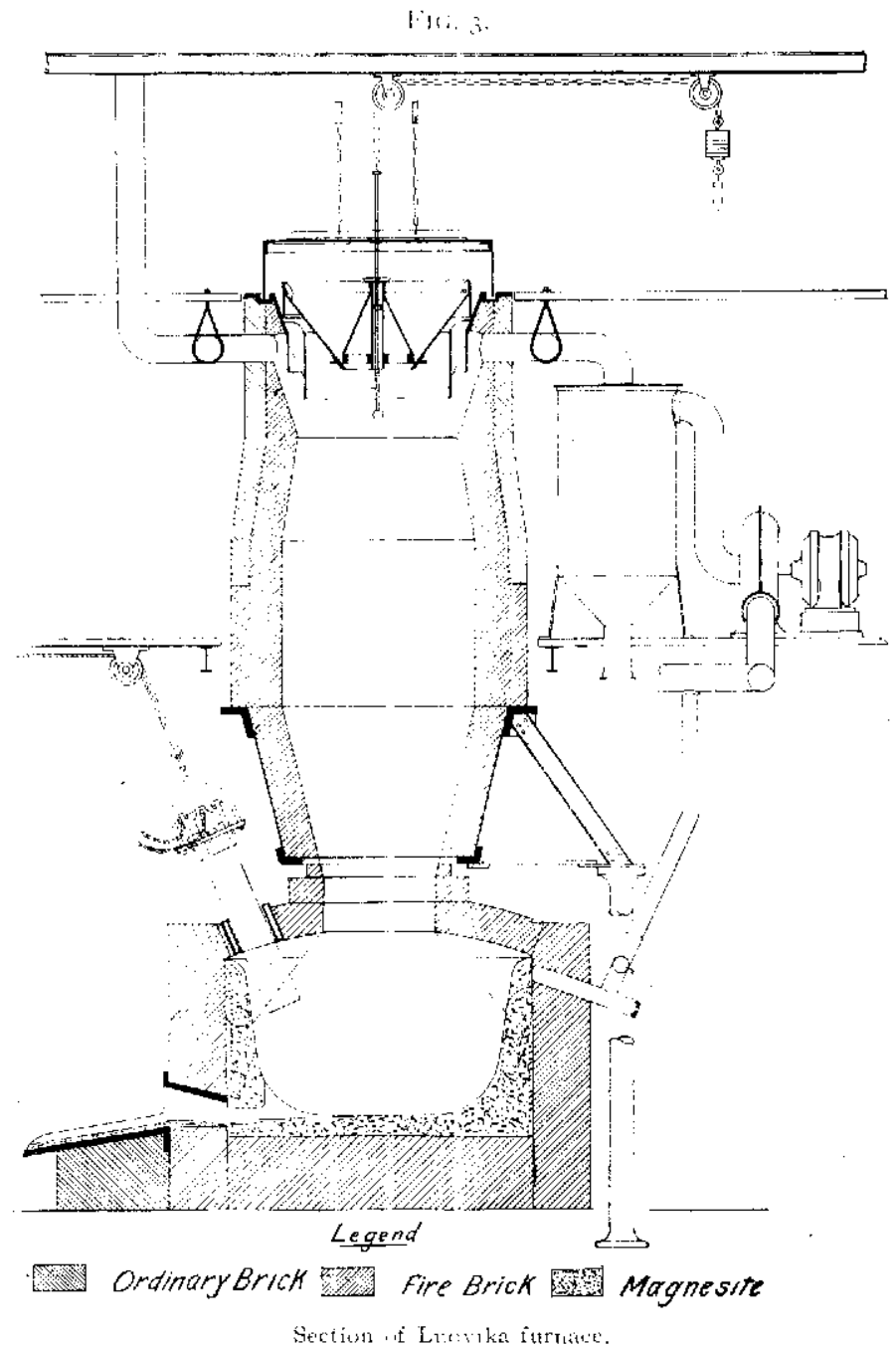

crucible is 7 feet high, the shaft 18 fect. The cntire weight of the npper shaft is carried on six cast-iron columns none of it rests on the arch covering the artibib. This arched roof has 
openings for the three electrodes, each composed of two carbons I I in. square by 63 in. long, making each electrode $I$ I in. by 22 in. by $63 \mathrm{in}$. The electrode holder is a steel frame into which the electrodes are fastened by copper wedges. The electrodes pass through water-cooled stufting boxes. The crucible is lined with magnesite-brick-a material never usable in blast-furnaces. Some of the escaping furnace gas is pumped back by means of a fan into the free space under the crucible arch, for the purpose of cooling off that arch and so preserving it from the intense radiated heat.

The electric current is supplied as three-phase current to the three clectrodes by three transformers of 500 kilo-voltamperes each, transforming the current down to $\mathrm{I} / \mathrm{I} 4$ its primary voltage, and capalse of regulation between 20 and 85 volts.

The especially novel features are the arch over the crucible, the projecting downwards of the electrodes through this arch into contact with the charge as it spreads out from the central shaft into the crucible, the magnesia lining, and the return of part of the throat gases into the crucible under the arched roof. It can readily be seen that a large amount of thought and experience are embodied in the details of this furnace.

A trial run was made under Dr. Haancl's inspection, starting with the cold furnace. Besides the handicap of starting cold, and with all the masonry fresh, the furnace was insufficiently supplied with power. Instead of the $1500 \mathrm{kw}$. which it was designed for, only about 400 could be gotten. Under these circumstances, the losses of heat by radiation and conduction were probably almost so great intrinsically as they would have been with full power, which means that they were relatively, or proportionately to the energy used, probably three or four times as great. The result of the test is therefore far from indicating the maximum commercial efficiency of this furnace.

In spite of these adverse conditions, pig-iron was made from the ore at the rate of 0.40 electric horse power year consumed per metric ton of pig-iron. The fuel consumed for reduction was $27.5 \mathrm{~kg}$. of coke per 100 of pig-iron, and of electrodes $5 \mathrm{~kg}$. It is altogether reasonable to assume that the power consumption, when in regular running, will not exceed 0.3 e. h. p. year, and on this basis, counting power at $\$ 12$ per e. h. p. year and charcoal ( 8,3 per cent. carbon) at $\$ 8.00$ per 
metric ton (2204 Ibs.), Professor Odelstjerna, of Stockholm, has estimated that pig-iron can now be made, in Sweden, in this furnace, at $\$ 1.50$ per ton less than in Swedish blast-furnaces. It is my opinion that this furnace, if run at $3000 \mathrm{kw}$., could make pig-iron at 0.2 e. h. p. year per ton of output, making a further saving of $\$$ г.20 per ton. With a prospective saving of $\$ 2.50$ per ton, the Swedish blast-furnace industry stands a good chance of being superseded by the electric furnace, as soon as the latter gets into proper working order.

Accompanying diagrams are intended to illustrate the fundamental principles of electric furnace reduction of iron ore.

FIG. 4 .

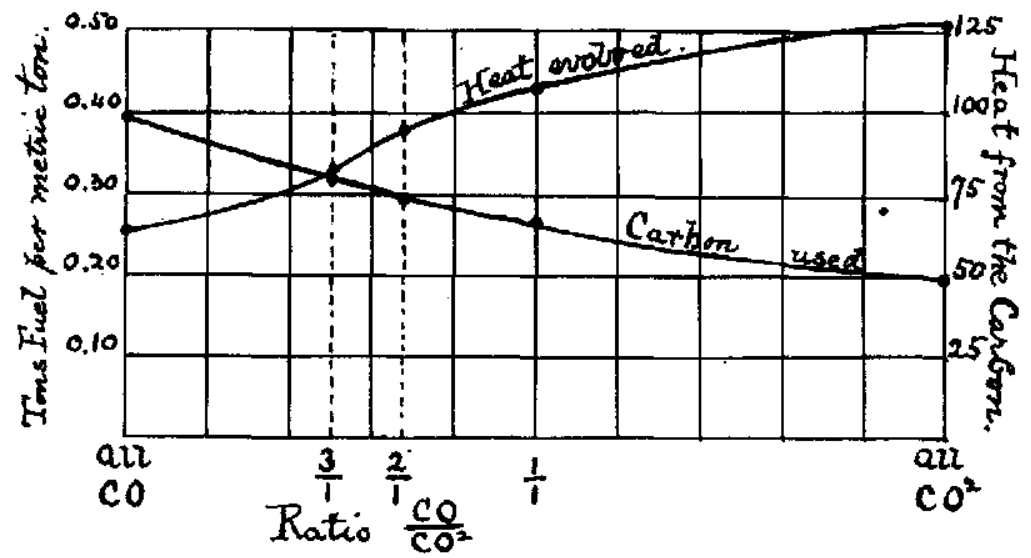

Vuriation of fuel required and heat evolved, with composition of waste gases produced.

They are entirely dependent upon the rate at which the furnace is run and the proportion of $\mathrm{CO}$ to $\mathrm{CO}_{2}$ in the gases. In the latter respect, a proportion of I : I by volume is entirely practicable and should be attained in electric smelting, although $2: \mathrm{I}$ is the usual ratio in blast-furnace practice. A kilogramme of oxygen burning carbon to CO gives up I 820 heat units (calories), but if burning (only half as much) carbon to $\mathrm{CO}_{2}$ it gives up 3075 calories. Since there is a definite amount of oxygen to be removed per ton of pig-iron made, more assistance is obtained from the combination of carbon and oxygen the nore $\mathrm{CO}_{2}$ and the less $\mathrm{CO}$ is formed. Fig. 4 shows the heat evolved, in units of Iooo calories, as the ratio of $\mathrm{CO}: \mathrm{CO}_{2}$ varies from all 


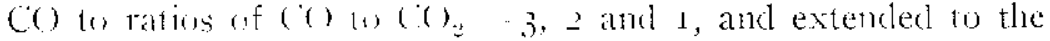
supposed case of all (o) being formed. Tt show graphically (lic fact that the smaller the annownt of carbon used the more

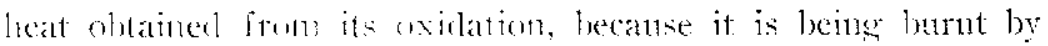
a lixed guantity of rexgent.

lexperiments on the ralution al iron oxisles in currents of

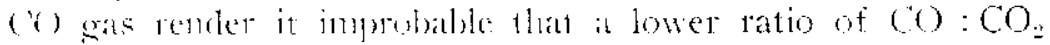

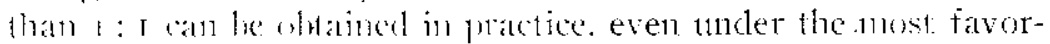
alike dectrie Fumace conditions. This corresponds to 0.26 tom of carlun per ton of pige iron makle, and a thermal assistance

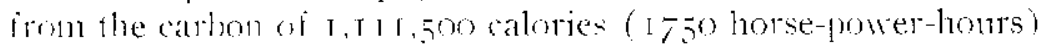
per tom al irom.

Hisi. 5.

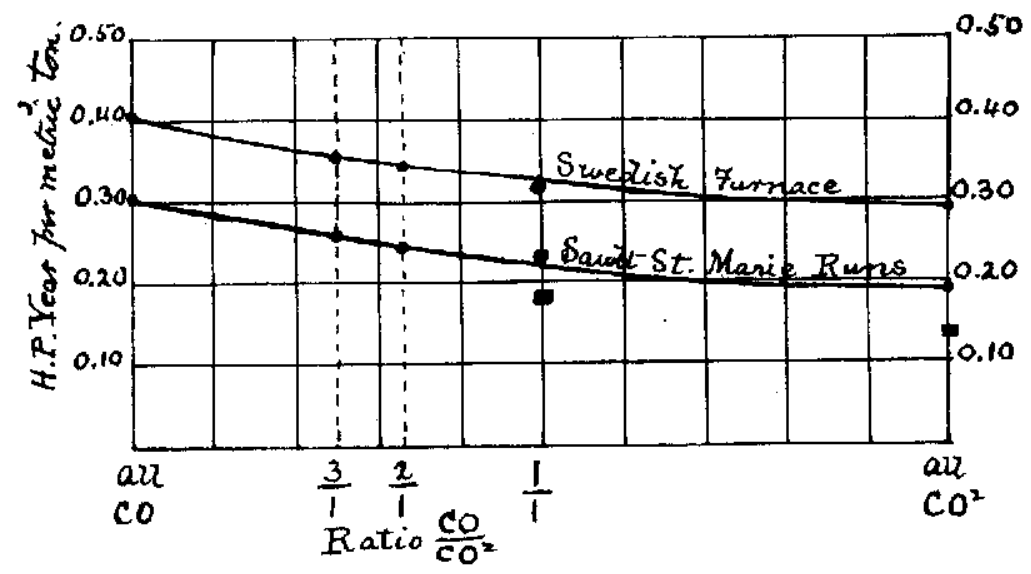

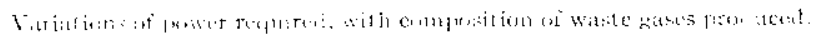

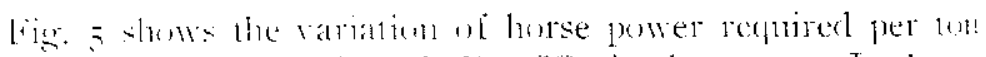

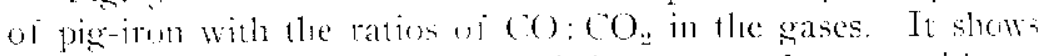

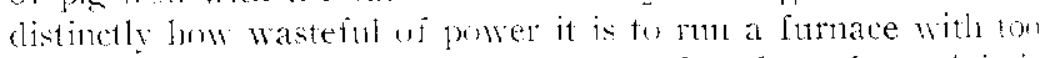
much carbon: with a certats anount of carbon charged it is practically imposible to atilize it except it burns mostly to Co. and then the high power consumption is the result of the lacts af proper thermal assistance from the carlon. The power curve of the Swedish furnace is alove those of the S. S. Maric runs. for the satne fuel consumption or ratio of $\mathrm{CO}: \mathrm{CO}$, because tle former furnace was being run at not over one-fonth, possibly nearer one-sixtli, of its proper power supply. while the 
latter furnace was small atml was pushed harl. The difference of o.I h. p. year per ton of pig-iron mate is probably entirely ascribable to high raliation and conduction losses, due to the relatively slow rumning.

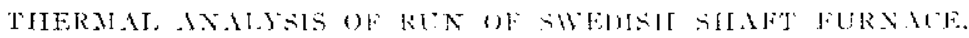

Dr. Hatanel gives sufficiont dana for forming a yood idea of the heat distribution in llo harge Sweelish furnace. The rata are as follows:
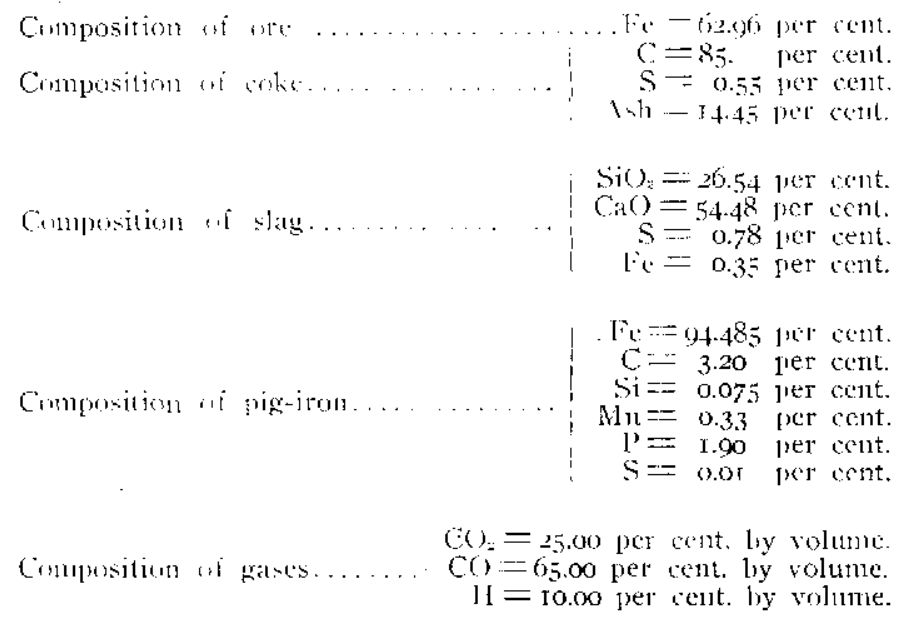

Clatrges: (Ire, 220): Colit. 37.4 : ] Jime, 4.4 .

from the alove data it can be calculated, assuming the gatses escaping at 250 and the pig-iron and slag at a little alme blast-furnace temperature. that the energy received and clistributed by the furnace is almut as follows, per roo $\mathrm{kg}$. of pig-iron concernecl:

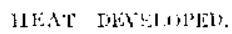

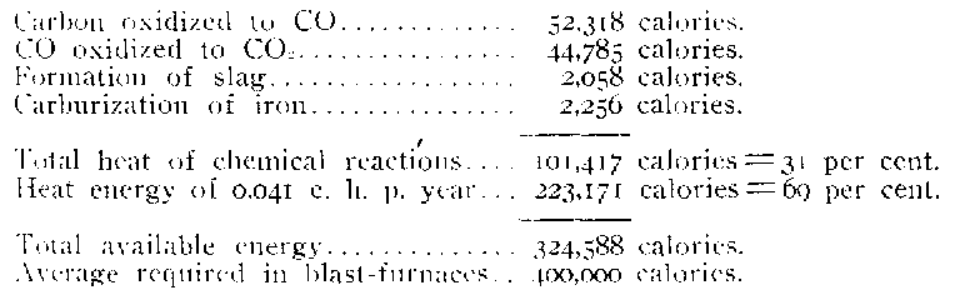


HKIT DISTRIHUTION.

Reduction of iron axide........ $155.22 \mathrm{I}$ calories $=48$ per cent.

Reduction of other oxidls....... 10,174 calorics $=3.5$ per cent.

Eyaporation of water.......... 1,025 calories $=0.3$ per cent.

Sensible heat in watste girses..... 4.075 calories $=1.3$ per cent.

Sensible heat in pig-irnn....... 32,500 calories $=10.0$ per cent.

Scnsible heat in slag. ......... 8,600 calories $=2.7$ per cont.

Rad'n and cond'n lusi tilit. . . . 112,850 calories $=33.2$ per cent.

The las item of the alowe scherlule is rery much larger than it slonkl be. Sonne molern blast-furnaces run with onetenth that much. The orouble with this fumace was that it was run only about onc-1enth as fast as it shonld be for heat economy. li we asstme that this furnace is rm last and carefully, so as to get a ratio $\mathrm{CO}: \mathrm{CO}_{2}$, in the gases of $1: 1$, we can estimate what will be the probable ruming of a large electric pig-iron furnace, such as will molouberlly be in stearly operation in the noar fulure. The recuirencut for power will be that necessary to furnisl the neederl heat, less that furnished by the chemical reactions. These will be per $10 n$ of pig-iron produced:

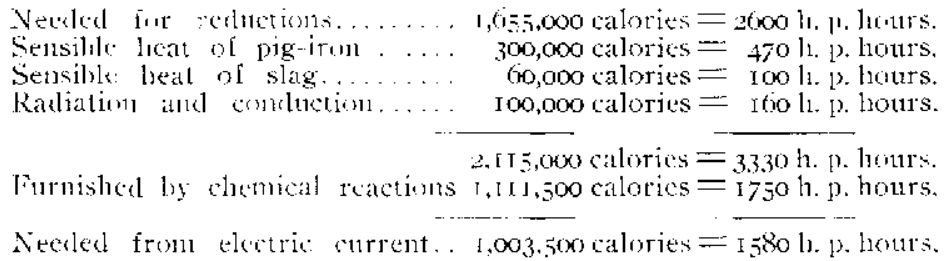

The following is llerefore the conclusion of this inestigattion:

I/ a larger alectric shaft furnace is run rapidly, with abundant power. and the gases iscaping contain at least as much $C^{\circ}$. (by aolume) as (C). Whe minmum pocer requiroment ahich will be approximated is $1.580 \mathrm{~h}$. p. hours, or $0.18 \mathrm{~h}$. p. years, por metrit ton (2204 lbs.) of pig-iron produced.

One ton per 0.226 1. p. Year las alreacly been reached in an experincntal run. 